\title{
Maize Lethal Necrosis (MLN), an Emerging Threat to Maize-Based Food Security in Sub-Saharan Africa
}

\author{
George Mahuku, Benham E. Lockhart, Bramwel Wanjala, Mark W. Jones, Janet Njeri Kimunye, Lucy R. Stewart, Bryan J. \\ Cassone, Subramanian Sevgan, Johnson O. Nyasani, Elizabeth Kusia, P. Lava Kumar, C. L. Niblett, Andrew Kiggundu, \\ Godfrey Asea, Hanu R. Pappu, Anne Wangai, Boddupalli M. Prasanna, and Margaret G. Redinbaugh
}

First, fifth, and seventeenth authors: International Maize and Wheat Improvement Center (CIMMYT), ICRAF Campus, UN Avenue, Gigiri, PO Box 1041-00621, Nairobi, Kenya; second author: Department of Plant Pathology, University of Minnesota, St. Paul; third and sixteenth authors: Kenya Agricultural and Livestock Research Organization (KALRO), Nairobi, Kenya; fourth, sixth, seventh, and eighteenth authors: United States Department of Agriculture-Agricultural Research Service Corn, Soybean and Wheat Quality Research and Department of Plant Pathology, Ohio State University, Wooster 44691; eighth, ninth, and tenth authors: Plant Health Division, International Centre of Insect Physiology and Ecology, P.O. Box 30772-00100, Nairobi, Kenya; eleventh author: International Institute of Tropical Agriculture (IITA), PMB 5320, Ibadan, Nigeria; twelfth author: Venganza, Inc., 9505 Ocean Shore Blvd., St. Augustine, FL 32080; thirteenth and fourteenth authors: National Agricultural Research Organization, Entebbe, Uganda; and fifteenth author: Department of Plant Pathology, Washington State University, Pullman 99164.

Current address of G. Mahuku: International Institute of Tropical Agriculture, PO Box 34441, Dar es Salaam, Tanzania.

Accepted for publication 11 March 2015.

\begin{abstract}
Mahuku, G., Lockhart, B. E., Wanjala, B., Jones, M. W., Kimunye, J. N., Stewart, L. R., Cassone, B. J., Sevgan, S., Nyasani, J. O., Kusia, E., Kumar, P. L., Niblett, C. L., Kiggundu, A., Asea, G., Pappu, H. R., Wangai, A., Prasanna, B. M., and Redinbaugh, M. G. 2015. Maize lethal necrosis (MLN), an emerging threat to maize-based food security in subSaharan Africa. Phytopathology 105:956-965.

In sub-Saharan Africa, maize is a staple food and key determinant of food security for smallholder farming communities. Pest and disease outbreaks are key constraints to maize productivity. In September 2011, a serious disease outbreak, later diagnosed as maize lethal necrosis (MLN), was reported on maize in Kenya. The disease has since been confirmed in Rwanda and the Democratic Republic of

Congo, and similar symptoms have been reported in Tanzania, Uganda, South Sudan, and Ethiopia. In 2012, yield losses of up to $90 \%$ resulted in an estimated grain loss of 126,000 metric tons valued at \$52 million in Kenya alone. In eastern Africa, MLN was found to result from coinfection of maize with Maize chlorotic mottle virus (MCMV) and Sugarcane mosaic virus (SCMV), although MCMV alone appears to cause significant crop losses. We summarize here the results of collaborative research undertaken to understand the biology and epidemiology of MLN in East Africa and to develop disease management strategies, including identification of MLN-tolerant maize germplasm. We discuss recent progress, identify major issues requiring further research, and discuss the possible next steps for effective management of MLN.
\end{abstract}

Maize (Zea mays L.) is the most important cereal crop in subSaharan Africa (SSA), covering over 25 million ha, largely in smallholder farming systems that produce over 38 million metric tons (MMT) of grain (FAOSTAT 2010). This represents $34 \%$ of cereal production and is $8 \%$ of the value of all crops in the region. Maize is critical for food security in SSA; eastern and southern Africa use $85 \%$ of the maize produced as food, while Africa as a whole uses $95 \%$ as food (Shiferaw et al. 2011).

In Kenya, a serious disease outbreak, later diagnosed as maize lethal necrosis (MLN) (Wangai et al. 2012b), was first reported in September 2011 in the Longisa Division of the Bomet District. By 2012, symptoms consistent with MLN were observed in a number of districts in the Central, Nyanza, Western, and Rift Valley Provinces of Kenya (Wangai et al. 2012a). Since then, the disease has been reported from Rwanda (Adams et al. 2014) and Democratic Republic of Congo (DRC) (Lukanda et al. 2014). Similar symptoms on maize have been reported from Uganda and

Corresponding author: P. Redinbaugh;

E-mail address: peg.redinbaugh@ars.usda.gov

*The $\boldsymbol{e}$-Xtra logo stands for "electronic extra" and indicates that two supplementary figures are published online.

http://dx.doi.org/10.1094/PHYTO-12-14-0367-FI

This article is in the public domain and not copyrightable. It may be freely reprinted with customary crediting of the source. The American Phytopathological Society, 2015.
Tanzania (Wangai et al. 2012a) and, more recently, from South Sudan and Ethiopia (G. Mahuku and A. Wangai, unpublished results). In Kenya, field observations suggested that the disease was affecting almost all commercial maize varieties, causing estimated yield losses of 30 to $100 \%$ depending on the stage of disease onset and severity. In 2012, MLN affected 77,000 ha in Kenya alone, translating into an estimated yield loss of 126 MMT valued at U.S.\$52 million (Wangai et al. 2012a).

MLN is caused by synergistic coinfection of maize with Maize chlorotic mottle virus (MCMV) from the genus Machlomovirus in the family Tombusviridae and a virus from the family Potyviridae, especially Wheat streak mosaic virus (WSMV), Maize dwarf mosaic virus (MDMV), or Sugarcane mosaic virus (SCMV, formerly MDMV-B) (Goldberg and Brakke 1987; Niblett and Claflin 1978; Uyemoto et al. 1980). Several other, unrelated viruses can also cause synergistic reactions in coinfections with MCMV, and abiotic stresses can exacerbate MCMV infection to cause MLN (Redinbaugh and Zambrano-Mendoza 2014). Maize-infecting potyviruses are common; SCMV, in particular, has a worldwide distribution and has been known in Kenya since the 1970s (Louie 1980). Thus, emergence of MCMV infection in maize is generally sufficient to trigger MLN.

In this report, we summarize current knowledge about MLN and the recent outbreak in eastern Africa. We present results on the distribution of MCMV and SCMV in Kenya, Uganda, and Tanzania, and use next-generation sequencing (NGS) to show 
that MCMV sequences from western Kenya are highly similar but SCMV sequences have significant diversity. Potential alternative hosts of MCMV are identified. Roles for thrips species, seed, and soil in MCMV transmission are identified. We show differential responses of maize germplasm to inoculation with MCMV and SCMV. These new results are discussed along with critical gaps in our knowledge about MLN and its spread in eastern Africa.

\section{HISTORY AND BIOLOGY OF MLN}

MLN, originally termed corn lethal necrosis (CLN), was identified and described in Kansas in the United States in 1977 (Niblett and Claflin 1978) as being caused by the synergistic interaction of MCMV and either MDMV or WSMV (Table 1). Thereafter, it was reported in Nebraska (Doupnik 1979), Hawaii (Jiang et al. 1992), China (Xie et al. 2011), and Kenya (Wangai et al. 2012b). In China, MCMV was identified in combination with SCMV (Xie et al. 2011). SCMV was identified in Kenya (Louie 1980; Wangai et al. 2012b) and has been associated with MLN in all the African countries to date.

MLN symptoms include a bright mosaic developing into tissue chlorosis and necrosis, with severe plant stunting and death or a severe necrosis of terminal leaves (Niblett and Claflin 1978; Uyemoto et al. 1981) (Fig. 1A). Plants that are infected late in development remain unproductive, and are barren or bear small, partially filled, malformed ears (Uyemoto et al. 1981). In maize coinfected with MCMV and a potyvirus, MCMV concentrations were 3 to 11 times higher than in plants infected with MCMV alone (Goldberg and Brakke 1987, Scheets 1998). In the United States, yield losses as high as $90 \%$ have been reported due to CLN (Niblett and Claflin 1978; Uyemoto et al. 1980).

MCMV was first described in Peru and the United States and, later, in Argentina, Thailand, Mexico, Hawaii, and Colombia (Table 1). Since 2010, however, MCMV has emerged at several locations in the Eastern Hemisphere, including China and Taiwan, in addition to eastern Africa. The extensive overlap of MLN and MCMV indicates that it is a primary disease problem wherever MCMV occurs.

Maize-infecting viruses in the family Potyviridae were first described in the 1960s from Ohio in the United States (Redinbaugh and Zambrano-Mendoza 2014). Of these, MDMV and SCMV cause the most widespread disease of maize worldwide. SCMV is found worldwide, and MDMV is distributed widely in the Western Hemisphere and Europe. In addition, Sorghum mosaic virus, Johnsongrass mosaic virus, and WSMV cause disease on maize in limited areas. Other viruses, including Maize rayado fino virus and Maize mosaic virus, can also cause synergistic reactions in coinfections with MCMV, and abiotic stresses can also exacerbate MCMV infections (Castillo-Loayza 1976; Nelson et al. 2011).

\section{INCIDENCE AND PREVALENCE OF MLN CAUSING VIRUSES IN EAST AFRICA}

Surveys of maize fields in Kenya, Uganda, and Tanzania were carried out during 2012 to 2014 to determine the distribution of MCMV and SCMV based on symptom monitoring and assessment of virus presence in leaves by enzyme-linked immunosorbent assay (ELISA) (Table 2) or tissue blot immunoassays (Jones et al. 2011). A high incidence (7 to $94 \%$ ) of MCMV was found in both symptomatic and randomly selected plants (Table 3). In general, SCMV incidence was lower than MCMV incidence, and similar to the rate of coinfection with MCMV and SCMV. The incidence of MCMV in symptomatic plants collected in the Western region of Kenya increased from 2013 to 2014 (Table 3, survey A), suggesting increasing disease pressure. However, better awareness of disease symptoms and skill in identifying symptomatic plants could have also played a role. In symptomatic plants collected from across Uganda during the second half of 2013, 62 and 23\% of the samples were infected with MCMV and SCMV, respectively. Nearly all of the SCMV-infected plants were coinfected with MCMV. Very few samples in this survey carried Maize streak virus (MSV) (data not shown). In the Arusha and Mwanza Districts of Tanzania, 60 and $69 \%$ of the samples collected were infected with MCMV and SCMV, respectively, with most samples being infected with both viruses. A survey of the major maize growing regions of Kenya in 2013 to 2014 (survey D) indicated that $60 \%$ of the 2,467 randomly selected samples were positive for MCMV, with more than $40 \%$ of these being infected with MCMV alone. Only $28 \%$ of the samples contained SCMV, and very few were infected with SCMV alone. Previously, MCMV was detected in 40 to $80 \%$ of symptomatic samples collected from the Beni, Lubero, and Rutshuru territories of North Kivu Province in the DRC in 2013 (Lukanda et al. 2014).

The survey results indicate that MCMV is widely distributed in Kenya, Uganda, DRC, and Tanzania. The frequency of virus infection was quite high in all of the surveys, including those using randomly selected samples. Although the incidence of MLN (i.e., MCMV + SCMV) was significant (18 to 43\%), the high incidence of MCMV alone in symptomatic plants suggests that MCMV alone can cause disease development. However, it is also possible that undetected SCMV isolates (see discussion below), other viruses, or abiotic factors complicate the etiology of MLN in eastern Africa. It is important to conduct similar surveys in other SSA countries, especially in areas not yet suspected to have MCMV or MLN, to ascertain the possible presence or extent of incidence of MCMV, and to determine what other viruses, pathogens, and abiotic factors play a role in disease development. Preemptive surveys for SCMV and MLN-like diseases at 218 locations in eight states in Nigeria in 2014 revealed that MSV was present in approximately $20 \%$ of plants in $66 \%$ of fields but neither SCMV nor MCMV was detected using ELISA (data not shown). This information will be

TABLE 1. Chronological reports of Maize chlorotic mottle virus (MCMV) occurrence

\begin{tabular}{|c|c|c|c|}
\hline Location & Date reported & Potyvirus $^{\mathrm{y}}$ & Reference \\
\hline Peru & 1973 & NR & Castillo and Herbert 1974 \\
\hline United States, mainland & 1976 & WSMV/MDMV & Niblett and Claflin 1978 \\
\hline Argentina & 1982 & NR & Teyssandier et al. 1981 \\
\hline Mexico & 1989 & NR & Carrera-Martinez et al. 1989 \\
\hline United States, Hawaii & 1992 & MDMV & Jiang et al. 1992 \\
\hline Colombia & 1999 & NR & Morales et al. 1999 \\
\hline China & 2011 & NR & Xie et al. 2011 \\
\hline $\mathrm{DRC}^{\mathrm{z}}$ & 2013 & SCMV & Lukanda et al. 2014 \\
\hline Taiwan & 2014 & SCMV & Deng et al. 2014 \\
\hline
\end{tabular}

${ }_{\mathrm{y}}$ Potyviruses reported with MCMV: NR = not reported, WSMV = Wheat streak mosaic virus, MDMV = Maize dwarf mosaic virus, and SCMV = Sugarcane mosaic virus.

${ }^{\mathrm{z}} \mathrm{DRC}=$ Democratic Republic of the Congo 
particularly useful for establishing containment protocols and developing seed production and distribution strategies.

\section{THE VIRUSES CAUSING MLN}

MCMV. MCMV has 30-nm icosahedral virions encasing an approximately 4.4-kb single-stranded, positive-sense RNA genome (Fig. 1D) (Scheets 2004). The viral genome encodes six overlapping open reading frames, five of which are required for replication and movement in the plant (Fig. 1F). The virus causes an array of symptoms in maize, ranging from mild chlorotic mottling to severe mosaic and stunting, yellowing and necrosis, premature plant death, shortened male inflorescences with few spikes, or shortened, malformed, partially filled ears, depending on the plant's genetic background, its developmental stage at the time of infection, and prevailing environmental conditions (Fig. 1B). Yield losses range between 10 to $15 \%$ in natural infections and up to $59 \%$ inoculated maize plots (Uyemoto et al. 1981)

NGS using the Illumina HiSeq platform was used to sequence MCMV isolates from symptomatic maize samples collected in Navaisha and Bomet, Kenya in 2012 (Wangai et al. 2012b). Using the analysis pipeline and software parameters described by Stewart et al. (2014), a single full-length MCMV contig (4,452 bp; GenBank accession number KP851970) was obtained and aligned with genome sequences of $12 \mathrm{MCMV}$ isolates available in GenBank (Supplementary Fig. S1). The sequence obtained for this MCMV isolate was $99 \%$ identical to one isolate previously reported from Kenya (Adams et al. 2013) and four from Rwanda (Adams et al. 2014). The contig sequence also had $99 \%$ identity with MCMV isolates from maize and sugarcane collected in Yunnan and Sichuan, China; 98\% identity with another MCMV isolate from Yunnan, China (GU138674); and 96 to 97\% identical to genome sequences of MCMV isolates from Kansas and Nebraska in the United States. Similarly, partial sequences of the MCMV coat protein for isolates from Tanzania and DRC were 99\% identical to those from Kenya and Rwanda (data not shown). These results suggest a potentially common origin for eastern African and some Asian MCMV isolates. The high degree of sequence identity among eastern African MCMV isolates indicates that molecular diagnostic assays useful for detecting MCMV in samples from across the region can be deployed.

Insect vectors of MCMV. MCMV can be experimentally transmitted in a semipersistent manner by a number of Chrysomelid beetles, including several Diabrotica spp. (Nault et al. 1978). More recently, maize thrips (Frankliniella williamsi) were identified as vectors of MCMV (Cabanas, et al. 2013). A recent report suggested that western flower thrips (F. occidentalis) may also be a vector (Zhao et al. 2014); however, attempts to transmit the Kenyan isolate of MCMV with F. occidentalis were unsuccessful (data not shown). Like beetles, thrips transmitted MCMV after acquisition periods of $3 \mathrm{~h}$, with no evidence for a latent period; both larvae and adults retained the ability to transmit the virus for up to 6 days after acquisition (Cabanas et al. 2013). The range of vectors for MCMV in Africa is not known, although thrips have been observed in all fields where maize is grown, including in MLN- and MCMVaffected fields. It is possible that thrips and other vectors could be playing a major role in MCMV movement within and between fields in the affected countries in Africa. Maize thrips were reported in East Africa in 2009 (Moritz et al. 2013; Nyasani et al. 2012), and surveys of maize in Kenya and Uganda between 2008 and 2010 indicated that the vector was present in almost every maize-growing region from the coast of Kenya to the borders of Uganda and DRC (Supplementary Fig. S2). Maize thrips were observed on several other graminaceous crops, including babycorn, rice, sorghum, and wheat, and were also observed frequently on onion (Moritz et al. 2013). The wide distribution of $F$. williamsi indicates that maize thrips were present in East Africa for several years prior to the first report of MLN.

Other than $F$. williamsi, surveys for thrips infesting maize in East Africa revealed the presence of several other species. Among 189 thrips specimens collected from 19 locations ( 5 to 10 maize plants per location), 6 F. occidentalis, 62 F. schultzei, 4 Scirothrips spp.,

TABLE 2. Enzyme-linked immunosorbent assays (ELISA) used in this study

\begin{tabular}{lcll}
\hline ELISA & Method & Type $^{z}$ & \multicolumn{1}{c}{ Source, reference } \\
\hline MCMV & A & DAS & Agdia \\
MCMV & B & DAS & Clark and Adams 1977 \\
SCMV & C & DAS & Agdia \\
SCMV & D & Indirect & Lommel et al. 1982
\end{tabular}

y ELISA uses were either commercial kits obtained from Agdia, Inc. (Elkhart, IN) or were done as indicated using primary antibodies raised against a Hawaiian isolate of Maize chlorotic mottle virus (MCMV) (method B) and a Minnesota isolate of Sugarcane mosaic virus (SCMV) (method D).

z Double-antibody sandwich (DAS) or indirect ELISA were used, as indicated.
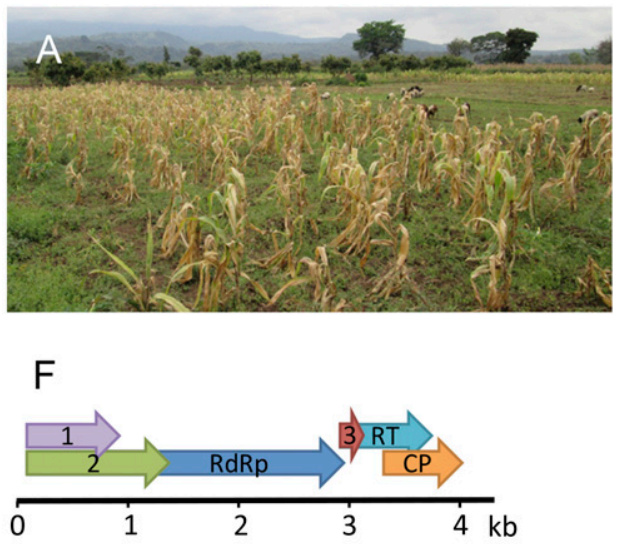

G
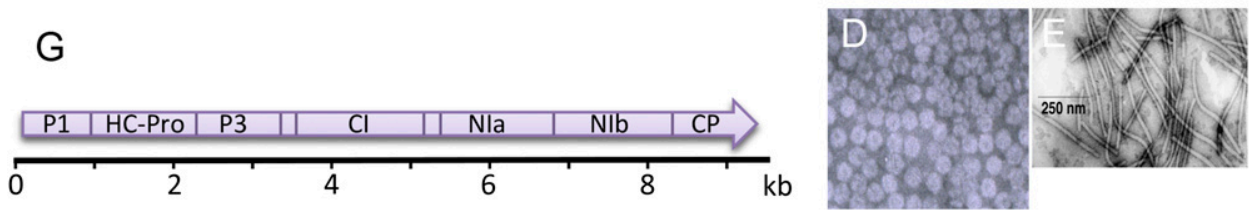

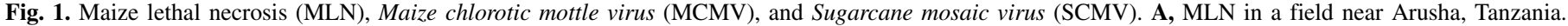
Maize infected with B, MCMV or C, SCMV. D, MCMV and E, SCMV virions. F, MCMV and G, SCMV genomes. 
and 3 Thrips tabaci, which are known vectors of tospoviruses (Riley et al. 2011), were identified. The highly polyphagous F. occidentalis, F. schultzei, T. pusillus, and T. tabaci are widely distributed in the region (Moritz et al. 2013). Preliminary experiments suggest that $F$. schultzei and T. tabaci as well as F. williamsi can transmit MCMV (J. Nyasani and S. Sevgan, unpublished results).

It remains possible that other vectors might be playing a major role in MCMV movement within and between fields in Africa. For instance, field collections of beetles from maize in Kenya revealed the presence of several Chrysomelid beetles such as Chaetocnema pulicaria that are potential vectors of MCMV (Nault et al. 1978). Further research is needed to determine the competence of these vectors in virus transmission, their ecology, and their role in the epidemiology of MLN. Robust diagnostic tools are available for thrips occurring in East Africa (Moritz et al. 2013) but such tools need to be developed for other potential vectors.

Host range of MCMV. Until recently, when MCMV was detected in sugarcane (Wang et al. 2014) and finger millet (Eleusine coracana) (Kusia et al. in press), maize was the only known natural host of MCMV (Scheets 2004). MCMV does not infect dicots, but has a broad experimental host range that includes at least 19 grass species (Bockelman et al. 1982). To examine the potential for nonmaize hosts of MCMV in East Africa, 14 grass species commonly found in maize fields were leaf-rub inoculated using extracts from MCMV-infected maize leaves. Uninoculated systemic leaves were assayed for the presence of virus using ELISA (Table 2, method B) or reverse-transcription polymerase chain reaction (RT-PCR) (Table 4, method B) at 7 to 10 weeks postinoculation. Twelve species were immune to MCMV, developing no symptoms and remaining free of MCMV as indicated by ELISA and RT-PCR: bermudagrass (Cynodon dactylon), napier grass (Pennisetum purpureum), common wild oat (Avena fatua), pearl millet ( $P$. glaucum), brome grass (Bromus inermis), sand lovegrass (Eragrostis trichodes), wheatgrass (Agropyron repens), barnyard grass (Echinochloa crus-galli), smooth crabgrass (Digitaria ischemum), nut grass (Cyperus esculentus), wheat (Triticum aestivum 'Fuller' and 'Hatcher'), and oat (Avena sativa 'Robust', 'Rasmusson',

TABLE 3. Incidence of Maize chlorotic mottle virus (MCMV) and Sugarcane mosaic virus (SCMV) in maize from Kenya, Uganda, and Tanzania over four growing seasons

\begin{tabular}{|c|c|c|c|c|c|c|}
\hline \multirow[b]{2}{*}{ Survey ${ }^{x}$} & \multirow[b]{2}{*}{ Location } & \multirow[b]{2}{*}{ Seasons ${ }^{y}$} & \multirow[b]{2}{*}{ Samples ${ }^{z}$} & \multicolumn{3}{|c|}{ Number ELISA positive $(\%)^{\mathrm{w}}$} \\
\hline & & & & MCMV & SCMV & MCMV + SCMV \\
\hline \multirow[t]{2}{*}{ A } & Western Kenya & 2013 I & 437 & $209(48)$ & $216(49)$ & $161(37)$ \\
\hline & & 2013 II & 87 & $51(59)$ & $25(29)$ & 19 (22) \\
\hline \multirow[t]{2}{*}{ B } & Western Kenya & 2013 I + II & 247 & $211(85)$ & $98(40)$ & $90(36)$ \\
\hline & Uganda & 2013 I + II & 52 & $32(62)$ & $12(23)$ & $11(21)$ \\
\hline \multirow{12}{*}{$\begin{array}{l}\text { C } \\
\text { D }\end{array}$} & Tanzania & 2012 II & 39 & $24(62)$ & 27 (69) & $20(51)$ \\
\hline & Busia & & 181 & $41(23)$ & 49 (27) & $4(2)$ \\
\hline & Elgeyo Marakwet & & 41 & $35(85)$ & $12(29)$ & $10(24)$ \\
\hline & Homabay & & 109 & $34(31)$ & $0(0)$ & $0(0)$ \\
\hline & Kakamega & & 41 & $11(27)$ & $13(32)$ & $2(5)$ \\
\hline & Kericho & & 174 & $146(81)$ & $79(45)$ & $72(41)$ \\
\hline & Kisumu & & 35 & $4(11)$ & $0(0)$ & $0(0)$ \\
\hline & Meru & & 107 & $48(45)$ & $1(1)$ & $0(0)$ \\
\hline & Siaya & & 109 & $33(30)$ & $0(0)$ & $0(0)$ \\
\hline & Trans Nzoia & & 131 & $117(89)$ & $53(41)$ & $48(37)$ \\
\hline & Uasin Gishu & & 184 & $12(7)$ & $0(0)$ & $0(0)$ \\
\hline & Pokot & & 100 & $37(37)$ & $8(8)$ & $0(0)$ \\
\hline
\end{tabular}

${ }^{\mathrm{w}}$ Data reported are the number of enzyme-linked immunosorbent assay (ELISA)-positive plants for MCMV, SCMV, or both viruses. For surveys A and B, leaves from symptomatic plants were evaluated using ELISA methods A and C. For survey C, leaves from symptomatic plants were tested using tissue blot immunoassay as previously described (Jones et al. 2011). For survey D, randomly selected samples were analyzed for the presence of MCMV and SCMV using ELISA methods B and D. Values presented are the number of positive plants (percent positive plants).

${ }^{x}$ For survey A, symptomatic leaves were collected from farmers fields in the Western and Nyanza Provinces of western Kenya in three maize seasons. For survey B, symptomatic leaves were collected from symptomatic maize in western Kenya and across Uganda. Survey C consisted of symptomatic plants collected from the Arusha and Mwanza districts of Tanzania. For survey D, 2,467 samples were collected from 17 counties within the Western and South Rift Valley regions of Kenya. For each county, three to five random samples of 10 leaves were pooled for analysis from each of three different fields.

y Maize growing seasons surveyed were the long-rains seasons (I) from March through August of 2012 to 2014 and the short-rains season (II) from September through January 2013

z Number of samples.

TABLE 4. Reverse-transcription polymerase chain reaction (RT-PCR) assays used in this study

\begin{tabular}{lcllc}
\hline Virus & Method $^{\mathrm{y}}$ & \multicolumn{1}{c}{ Forward primer } & \multicolumn{1}{c}{ Reverse primer $^{\text {Amplicon (bp) }}{ }^{\mathrm{z}}$} \\
\hline MCMV & A & 5'-ATGAGAGCAGTTGGGGAATGCG & 5'-CGAATCTACACACACACACTCCAGC & 2,681-3,226 \\
MCMV & B & 5'-CCGTGCTCCCCGGTATAAT & 5'-CTGAGTCCGCATTCCCCAAC 3' & 1,954-2,710 \\
SCMV & C & 5'-GCAATGTCGAAGAAAATGCG & 5'-GTCTCTCACCAAGAGACTCGCAGC & 8,679-9,596 \\
\hline
\end{tabular}

y For the methods A and C, RNA was isolated from lyophilized leaf tissue using Direct-zol (ZymoResearch, Irvine, CA) according to the manufacturer's recommendations, and RT-PCR was carried out according to Jarugula et al. (2010). For method B, RNA was isolated from fresh leaf tissue using the RNeasy Plant Mini Kit (Qiagen, Valencia, CA), and amplified using Illustra Ready-To-Go RT-PCR Beads (GE Healthcare, Pittsburgh).

${ }^{\mathrm{z}}$ Nucleotides of the Maize chlorotic mottle virus (MCMV) (GenBank accession NC003627) or Sugarcane mosaic virus (SCMV) (GenBank accession NC003398) genomic sequence amplified using the indicated primers. 
'Quest', 'Tradition', and 'Lacey'). Sorghum (Sorghum bicolor) was identified as a highly tolerant host of MCMV (i.e., MCMV was detected in systemic leaves from inoculated plants by RT-PCR) (data not shown) but the plants remained asymptomatic. Proso millet (Panicum miliaceum) developed mild symptoms, and finger millet and foxtail millet (Setaria italica) developed strong symptoms after MCMV inoculation, with the virus being detected in all three species by ELISA and RT-PCR. Symptomatic, field-collected samples of finger millet, sorghum, sugarcane, napier grass, and kikuyu grass (P. clandestinium) collected in Uganda and Kenya tested positive for MCMV by ELISA (Table 2, method A) (data not shown).

These results confirm the previous report by Bockelman and coworkers (1982), and indicate the possibility of a wider range of potential alternative hosts of MCMV that could serve as virus reservoirs. However, it is important to note that maize is cultivated throughout the year in most areas of eastern Africa. Under such conditions, maize itself could serve as a huge reservoir for MLNcausing viruses, especially MCMV. Nonetheless, some further analysis of grasses, especially those that are experimental hosts of MCMV, in and around maize fields is warranted. It is also important to establish the ability of insect vectors to transmit MCMV to maize from any putative alternative host to maize.

Seed transmission of MCMV. An earlier report indicated seed transmission rates of 0 to $0.33 \%$ for MCMV in 17 lots of maize seed from MCMV-infected plants (Jensen et al. 1991). However, even a low rate of seed transmission is epidemiologically significant, because a virus may be introduced into new areas through seed. Also, in conjunction with secondary spread by insect vectors, low rates of seed transmission can translate into high numbers of infected plants, resulting in epiphytotics (Maule and Wang 1996). To investigate the potential role of seed transmission in the spread of MCMV in Africa, RNA isolated from seed harvested from an MCMV-infected maize plant was tested for the presence of MCMV by RT-PCR (Table 4, method B); 18 of 25 seeds (72\%) were positive (data not shown). Further, MCMV was detected by RT-PCR of isolated RNA in 12 of 26 10 -seed samples pooled from 26 lots of locally purchased seed. Although it is clear that MCMV contaminates seed from virusinfected plants, the presence of MCMV in seed does not necessarily indicate that MCMV will be transmitted to progeny plants. Further research under strictly controlled conditions is urgently required to investigate the risk of seed transmission of MCMV and to determine the possible influence of maize genetic background and environmental factors on seed transmission.

Soil transmission of MCMV. To test the potential for MCMV transmission from soil, seed of maize hybrid SC513 produced in

TABLE 5. Transmission of Maize chlorotic mottle virus (MCMV) transmission from infected soil from Naivasha, Kenya

\begin{tabular}{lccc}
\hline Treatment $^{\mathrm{x}}$ & $\begin{array}{c}\text { Number of } \\
\text { plants tested }\end{array}$ & $\begin{array}{c}\text { Number } \\
\text { symptomatic }\end{array}$ & Infected $(\%)^{\mathrm{z}}$ \\
\hline Control soil & 23 & 1 & $4 \mathrm{a}$ \\
Infested soil & 71 & 49 & $69 \mathrm{~b}$ \\
\hline
\end{tabular}

${ }^{x}$ Seed used were maize hybrid SC513 produced in Zimbabwe, where MCMV has not been reported. Infested soil was obtained from in and around MCMV-infected plants from Naivasha, Kenya. Control soil was sterile soil purchased from Kenya Plant Health Inspectorate Service, Nairobi, Kenya. Some soil was sieved to remove infected plant debris, and samples were stored in a greenhouse for 1 to 49 days prior to planting seed into the infected soils.

${ }^{y}$ Number of plants with symptoms was recorded at 30 and 40 days after planting and the presence of MCMV was confirmed by enzyme-linked immunosorbent assay (ELISA). All plants were negative for Sugarcane mosaic virus by ELISA. Neither storage time nor the presence or absence of plant debris affected transmission. Results presented are for 24 replications of three plants per pot distributed over four storage times and two conditions ( \pm debris).

${ }^{\mathrm{z}}$ For the percentage of infected plants, means followed by the same letter are not statistically significant $(P<0.05)$.
Zimbabwe (where MCMV has not been reported) were planted into contaminated soil from MCMV-affected fields that had been stored for varying periods with or without maize stubble (Table 5). MCMV was detected in nearly $70 \%$ of the emerging seedlings planted into contaminated soil using ELISA (Table 2, method B) but only $4 \%$ of seedlings planted into sterile soil were infected. Research to determine the length of maize-free periods required to prevent MCMV transmission through soil is needed, as is investigation of a possible role for irrigation water in MCMV transmission.

Potyviruses-SCMV. In eastern Africa, SCMV has been identified as the primary potyvirus associated with MLN. SCMV is not new to Africa, having been described in Kenya (Louie 1980) and South Africa (Handley et al. 1998). SCMV is a member of the genus Potyvirus, family Potyviridae. All potyviruses have single-stranded positive-sense RNA genomes and flexuous rod-shaped virions of approximately 12 by $750 \mathrm{~nm}$ (Fig. 1E and G). SCMV is a phylogenetically diverse species for which genome sequences of isolates from maize and sugarcane cluster by host and geographic origin (Li et al. 2013), with sequence identities ranging from less than 70 to $99 \%$ (Fig. 2). Potyviruses cause mosaic symptoms and dwarfing in susceptible maize hybrids and cultivars, with the symptoms induced by SCMV generally being fairly mild (Fig. 1C). Maize-infecting potyviruses are naturally transmitted by approximately 25 aphid species in a nonpersistent manner (Brault et al. 2010). SCMV can also be seed transmitted with transmission rates of 0.4 to $3.9 \%$, depending on the genotype (Li et al. 2011).

To better understand diversity in SCMV from Africa, Illumina HiSeq analysis was used to determine the sequences of SCMV isolates collected in Navaisha and Bomet, Kenya in 2012 (Wangai et al. 2012b) and compare them with other isolates. Using the protocols and software outlined by Stewart et al. (2014), we identified eight contig sequences ranging from 793 to 6,321 bp with highest identity to SCMV genome sequences from China (BD8) or Rwanda (Table 6). In the clade containing the BD8 and Rwandan SCMV genome sequences (Fig. 2), the three Rwandan isolates share more than $90 \%$ identity with the Ohio SCMV isolate, and these four isolates have 78 to $79 \%$ identity with the BD8 isolate. Two of the eight contigs characterized in this study (contigs 1 and 10) had the highest sequence identity (98 to $99 \%$ ) with the BD8 isolate, while the remainder had the highest identity ( 87 to $99 \%$ ) with one of the Rwandan isolates. The three partial genome sequences previously reported from Kenya share their highest identity with the BD8 sequence (Adams et al. 2013), as do two partial genome sequences previously reported for SCMV isolates from Thailand (Table 6). These results indicate the presence of at least two groups of SCMV sequences in Kenya, one of which shares a common origin with isolates from Asia.

\section{MLN DIAGNOSTICS}

Detection methods for MCMV and SCMV. Rapid and sensitive diagnostic tools are critical for surveillance, early warning, and rapid implementation of prevention strategies. As in other crops, it is very difficult to diagnose virus diseases in maize based solely on symptoms, because these vary significantly based on genotype, time of infection, environmental conditions, and the potential for multiple infections. Therefore, visual diagnosis must be verified using serological assays such as ELISA or molecular tests such as RT-PCR.

Several different ELISA assays are available for MCMV and SCMV; however, these assays may not necessarily produce the same results for the eastern African isolates of the two viruses. For example, Adams and coworkers (2013) did not detect SCMV or MCMV using commercial ELISA kits, although they identified the sequences of both viruses in leaf tissue. Differences were also observed in the reactions of MCMV and SCMV to antisera raised to different virus isolates using the ELISA methods outlined in Table 2. A subset of 81 samples collected in Kenya (Table 3, survey 
D) was evaluated for MCMV and SCMV using methods B and D (Table 2), respectively, at Kenya Agricultural and Livestock Research Organization (KALRO) in Nairobi, and methods A and $\mathrm{C}$, respectively, at the United States Department of AgricultureAgricultural Research Service (USDA-ARS) in Ohio. For each virus, the results from the two analyses agreed for approximately $60 \%$ of the samples (data not shown). For MCMV, the primary difference was that more samples were positive with method A than with method B. For SCMV, the results were more complex. In all, $20 \%$ of the positive samples using method D were negative using method $\mathrm{C}$, and vice versa. The differential detection of viruses with the two methods was not likely to be due to low SCMV titer, because the absorbances for these samples in ELISA was similar to samples testing positive with each method (data not shown). These results suggest that the differences observed for SCMV may be inherent to the specific ELISA and the source of the antisera used, and could be the result of differences in the capsid protein sequence among the isolates. The identification of multiple isolates in samples collected in Kenya described above supports this conclusion.

RT-PCR, as expected, is more sensitive than ELISA for detecting MCMV. For example, MCMV was detected in 22 of 32 samples from Uganda by ELISA (Table 2, method A) and in 31 of the same samples by RT-PCR (Table 4, method A) (data not shown). For SCMV, RT-PCR (method C) and ELISA (method C) results were identical for 19 of the 32 samples. Two samples were RT-PCR positive and ELISA negative and four were ELISA positive and RT-PCR negative. For seven samples, the RT-PCR assay produced ambiguous results, with most of these samples coming from western Uganda. Similarly, real-time RT-PCR failed to detect SCMV in samples from Rwanda using primers designed for the Kenyan isolate of SCMV (Adams et al. 2014), and SCMV was not detected by

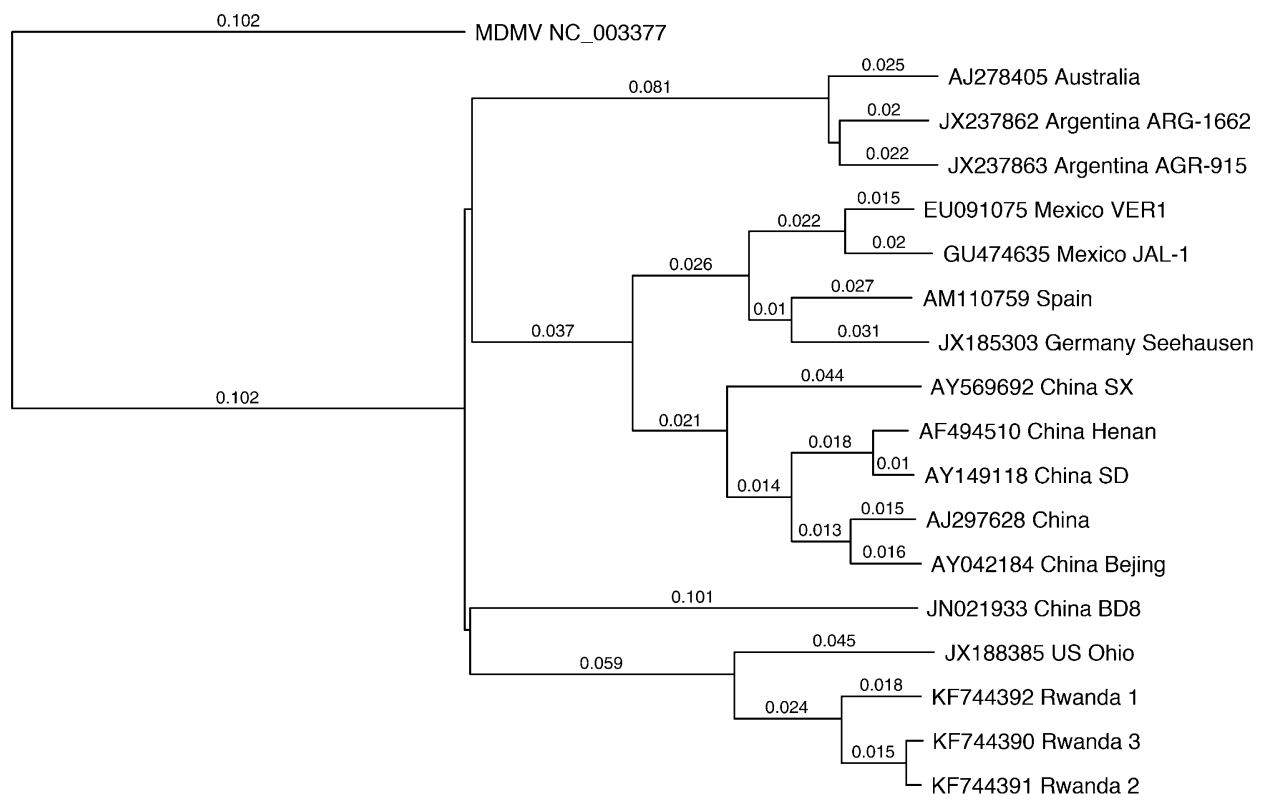

Fig. 2. Phylogenetic relationships among Sugarcane mosaic virus (SCMV) genome sequences. Genome sequences for SCMV isolates obtained from GenBank were aligned with the Clustal W algorithm in MacVector (v. 13.5; MacVector, Inc., Cary, NC). A neighbor-joining analysis using uncorrected $P$ values was used to generate the tree, and Maize dwarf mosaic virus (MDMV) was used as an outgroup. The best tree is shown. GenBank accession numbers and geographical origin for each isolate are shown.

TABLE 6. Comparison of partial genome sequences for Sugarcane mosaic virus isolates

\begin{tabular}{|c|c|c|c|c|c|c|c|c|c|}
\hline Sequence $^{v}$ & Accession $^{w}$ & Length $^{\mathrm{x}}$ & Genome $^{y}$ & Nucleotides $^{z}$ & BD8 & $\mathrm{R} 1$ & $\mathrm{R} 2$ & R3 & $\mathrm{OH}$ \\
\hline Contig 1 & KP835283 & 6,321 & BD8 & $416-6,729$ & 98 & 79 & 79 & 79 & 79 \\
\hline Contig 2 & KP835284 & 959 & Rwanda 1 & $4,371-5,328$ & 81 & 99 & 98 & 98 & 93 \\
\hline Contig 10 & KP835285 & 1,835 & BD8 & $6,920-8,754$ & 99 & 75 & 75 & 75 & 73 \\
\hline Contig 11.64 & KP835287 & 793 & Rwanda 1 & $2,914-3,705$ & 78 & 94 & 94 & 95 & 93 \\
\hline Contig 43.67.30.8.31.8010.74 & KP835288 & 1,679 & Rwanda 3 & $7,165-8,846$ & 76 & 98 & 97 & 96 & 87 \\
\hline Contig 42.114.111.52.101 & KP835289 & 1,560 & Rwanda 1 & $1,005-2,565$ & 73 & 90 & 90 & 88 & 86 \\
\hline Contig $62.16 .25 \mathrm{a} .25 \mathrm{~b}$ & KP835290 & 959 & Rwanda 1 & $5,765-6,722$ & 77 & 92 & 92 & 94 & 91 \\
\hline SCMV Kenya & JX286706 & 700 & BD8 & $149-847$ & 98 & 69 & 70 & 70 & 68 \\
\hline SCMV Kenya & JX286707 & 730 & BD8 & $6,110-6,835$ & 98 & 79 & 79 & 79 & 79 \\
\hline SCMV Kenya & JX286708 & 940 & BD8 & $8,399-9,339$ & 100 & 80 & 81 & 80 & 79 \\
\hline
\end{tabular}

${ }^{v}$ Sequences are contigs or supercontigs obtained from samples collected in western Kenya in survey A using RNASeq as previously described (Stewart et al. 2014). Supercontigs were assembled from contigs using Sequencher (Stewart et al. 2014).

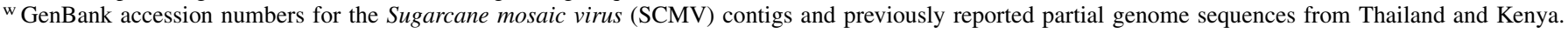

$x$ Sequence length in base pairs.

y SCMV genome sequence with the highest identity for the contig or partial genome sequence. Genome sequences were from China (BD8; JN021933), Rwanda 1 (R1, KF744392); Rwanda 2 (R2, KF744391), Rwanda 3 (R3, KF744390), and Ohio (JX188385).

$\mathrm{z}$ Nucleotides of the genome sequence corresponding to the contig or partial genome sequence determined from a pairwise comparison of sequences aligned with Clustal W. 
RT-PCR using either SCMV-specific or generic potyvirus primers in ELISA-positive samples collected from DRC (Lukanda et al. 2014).

Together, these results reveal the need to develop more robust assays for the virus isolates causing MLN, especially SCMV, potentially focusing on developing antisera and primers specific for East African virus isolates. With this intention, polyclonal antiserum was produced against the recombinant MCMV coat protein (721 nucleotides; $25 \mathrm{kDa}$ ) of a Tanzanian isolate expressed in Escherichia coli BL21(DE3) pLysS cells. The antiserum detected MCMV in leaf sap extracts at up to a $1: 20,000(\mathrm{vol} / \mathrm{vol})$ dilution of the antisera in ELISA. This antiserum needs to be tested against samples across the region and compared with other ELISA currently being used.

\section{DISEASE MANAGEMENT FOR MLN}

Vector control and agronomic practices. All of the economically important virus diseases of maize are transmitted by arthropod vectors. In Hawaii, the most effective control for MCMV has been achieved through the integration of cultural practices with suitable insecticides and host tolerance (Nelson et al. 2011). In the central United States, crop rotation was effective in reducing the incidence of MCMV (Phillips et al. 1982; Uyemoto 1983). In East Africa, however, it is not yet known what combination of vector management, improved agronomic management, and resistance will be best for managing MLN for smallholder farmers. At the KALRO-International Maize and Wheat Improvement Center (CIMMYT) Maize Experimental Station at Kiboko, Kenya, effective monitoring, rigorous implementation of maizefree periods, and rotation with noncereal crops have helped in minimizing MLN incidence (Fig. 3). Intensive integrated vector and cultural management practices could be useful for commercial production of virus-free maize seed. However, this intensive approach would be more difficult to implement for smallholder maize farmers in many areas of eastern Africa, where relay planting of maize and intercropping are common practices, and farmers lack awareness of and resources for vector control and cultural management practices.

Host resistance to MCMV and MLN in maize germplasm. Development of virus-resistant crops is an economically viable and environmentally sustainable approach for disease control but it

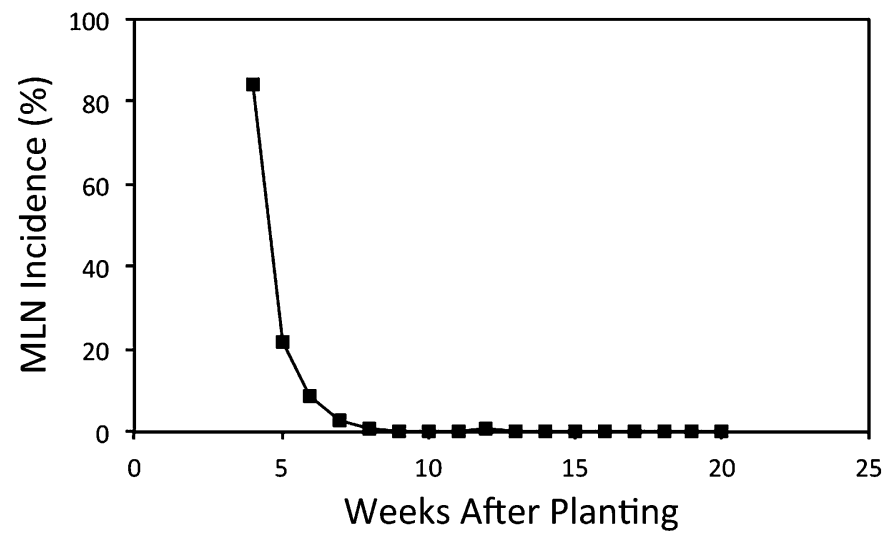

Fig. 3. Incidence of maize lethal necrosis (MLN) in a maize field in CIMMYT-KARLO experimental station of Kiboko, Kenya, in 2014. Monitoring of MLN-infected plants started 4 weeks after planting and continued weekly thereafter, until physiological maturity of the plants. Leaf samples were collected from suspected MLN plants, and diseased plants were removed and destroyed. Pesticide application started 2 weeks after planting using the following schedule: Carbosulfan $(250 \mathrm{~g} / \mathrm{liter})$ at weeks 2 and $3, \lambda$ cyhalothrin (17.5 g/liter) at weeks 4 and 5, Thiamethoxam $(250 \mathrm{~g} / \mathrm{kg})$ at weeks 6 and 7 , and $\beta$-cyfluthrin $(12.5 \mathrm{~g} / \mathrm{liter})+$ Chlorpyrifos $(250 \mathrm{~g} / \mathrm{liter})$ at weeks 8 and 9 . The cycle was repeated until physiological maturity. The presence of MLN viruses in leaf tissue was confirmed by enzyme-linked immunosorbent assay. requires identification and evaluation of resistant plants, then incorporation of favorable alleles into agronomically desirable genetic backgrounds. Several experiments have been undertaken in both Kenya and Ohio to identify sources of tolerance to resistance to MLN in elite maize germplasm.

To identify possible sources of resistance to MCMV and MLN, 63 maize inbred lines with resistance to multiple virus diseases, or for which there was some indication of MCMV resistance or tolerance in the literature, were tested for their responses to the Kansas isolate of MCMV under controlled conditions in Ohio and to local isolates of MCMV plus SCMV under artificial inoculation in field conditions in Kenya (Table 7). For the tests in Ohio, maize inbred lines that had responses similar to the susceptible control (inbred line Oh28) in the initial screening were not retained in two subsequent experiments, leaving 13 lines that were evaluated in all three experiments. Under controlled conditions, at least some plants for all lines developed symptoms by 4 weeks postinoculation. However, N211 and KS23-6 developed only mild symptoms late in the rating period. Several other lines had significant delays in symptom development relative to $\mathrm{Oh} 28$, including the inbred line Oh1VI, and six recombinant inbred lines derived from a cross of Oh1VI $\times$ Oh28 (Zambrano et al. 2014). At the end of the rating period, the plants were tested for the presence of MCMV using ELISA (Table 2, method A), and the virus was detected in all lines. The highest-ranking lines identified as MCMV resistant in Ohio also demonstrated some tolerance under field inoculation with both MCMV and SCMV in Kenya (Table 7), indicating their potential for this germplasm in developing MLN-resistant hybrids and cultivars for East Africa.

Genetics of resistance to MCMV and SCMV. An understanding of the genetic architecture of resistance to the MLNcausing viruses will facilitate effective development of resistant germplasm, hybrids, and cultivars. The genetics of resistance to potyviruses, including SCMV, is well understood, with major genes or quantitative trait loci (QTL) on the short arm of chromosome 6 (bin 6.01) and the long arm of chromosome 3 (bin 3.04/3.05) conferring resistance (reviewed in Redinbaugh and ZambranoMendoza 2014). In contrast, little is known about MCMV resistance in maize, although tolerant lines have been developed and tolerant hybrids are grown in Hawaii (Nelson et al. 2011, Redinbaugh and Zambrano-Mendoza 2014). In tolerant germplasm, the plants

TABLE 7. Responses of maize germplasm to inoculation with Maize chlorotic mottle virus (MCMV) under controlled conditions in Ohio and MCMV plus Sugarcane mosaic virus (SCMV) under field conditions in Kenyaw

\begin{tabular}{lcccccc}
\hline Maize line & DTFS $^{\mathrm{x}}$ & Rank & AUDPC & Rank & Rating $^{z}$ & Rank \\
\hline N211 & $26.0 \mathrm{~A}$ & 1 & 105.2 & 5 & $3.83 \mathrm{BCD}$ & 15 \\
KS23-6 & $25.6 \mathrm{~A}$ & 2 & 81.1 & 3 & $2.67 \mathrm{~A}$ & 3 \\
DR & $21.2 \mathrm{~B}$ & 3 & n.d. & $\ldots$ & n.d. & $\ldots$ \\
Oh1VI RIL 70332 & $18.8 \mathrm{BC}$ & 4 & 79.4 & 2 & $2.50 \mathrm{~A}$ & 2 \\
KS23-5 & $18.6 \mathrm{CD}$ & 5 & 71.9 & 1 & $2.00 \mathrm{~A}$ & 1 \\
Oh1VI & $16.3 \mathrm{DE}$ & 6 & 104.2 & 7 & $4.00 \mathrm{BCD}$ & 18 \\
Oh1VI RIL 70343 & $16.1 \mathrm{E}$ & 7 & 126.9 & 19 & $4.33 \mathrm{CDEF}$ & 22 \\
Oh1VI RIL 70340 & $16.0 \mathrm{E}$ & 8 & 109.9 & 8 & $3.50 \mathrm{~B}$ & 7 \\
Oh1VI RIL 70294 & $15.9 \mathrm{E}$ & 9 & 153.0 & 35 & $4.83 \mathrm{FG}$ & 42 \\
Oh1VI RIL 70279 & $15.7 \mathrm{E}$ & 10 & 117.2 & 13 & $4.00 \mathrm{BCD}$ & 17 \\
NC358 & $13.2 \mathrm{~F}$ & 11 & 153.6 & 39 & $5.00 \mathrm{G}$ & 47 \\
Oh1VI RIL 70228 & $11.2 \mathrm{~F}$ & 12 & 156.0 & 42 & $4.67 \mathrm{EFG}$ & 29 \\
Oh28 & $8.2 \mathrm{G}$ & 13 & 171.8 & 56 & $5.00 \mathrm{G}$ & 59 \\
\hline
\end{tabular}

w Values followed by the same letter within a column are not significantly different $(P>0.05)$; n.d. $=$ not done.

${ }^{x}$ DTFS $=$ the mean days to first symptoms for nine plants for each of 13 lines inoculated with the Kansas isolate of MCMV in three independent experiments in Wooster, OH. RIL = recombinant inbred line.

y Area under the disease progress curve (AUDPC) of three replicates for each of 63 lines in a field trial in Navaisha, Kenya inoculated with a combination of local isolates of MCMV and SCMV using the method of Meyer et al. (2010).

z Three replicate rows of 13 plants for each of 63 lines were rated on a scale of 1 (no symptoms) to 5 (dead plant) 8 weeks post first inoculation with local isolates of MCMV and SCMV. 
develop normally and produce an ear, even though the virus systemically infects the plants.

Results of genome-wide association studies (GWAS) and QTL mapping using biparental populations undertaken during 2012 to 2014 led to the identification of some genomic regions associated with resistance to MLN. Phenotyping was done using artificial inoculation with both MCMV and SCMV under field conditions, and genotyping included (i) 156 to 289 single-nucleotide polymorphisms (SNPs) using the KASP platform (Semagn et al. 2014) on the biparental populations and (ii) genotyping by sequencing on an association mapping panel of 616 tropical maize inbred lines. GWAS revealed nine SNPs that were significantly associated with MLN tolerance, as well as two significant QTL or genomic regions on chromosome 3 (bin 3.04/3.05) (data not shown). Preliminary analysis of the data from the biparental populations revealed three major QTL on chromosomes 3 and 6, in the same regions previously identified as important for virus resistance in maize in general and to potyvirus resistance in particular (Redinbaugh and ZambranoMendoza 2014). Minor QTL were identified across most maize chromosomes. The major QTL explained between 4 and $35 \%$ of the phenotypic variance, and the overall average was 45 to $47 \%$ of the variance in each population (Semagn et al. 2015). A QTL at bin 3.05 explained up to $30 \%$ of the phenotypic variance across the two populations. Further studies are ongoing to validate the major QTL detected, confirm their physical positions, and determine the relative contributions of potyvirus resistance and MCMV tolerance to the observed phenotypes. A marker-assisted backcrossing program is also being implemented by CIMMYT for accelerated conversion of approximately 25 widely used but MLN-susceptible maize inbred lines into MLN-resistant versions (Semagn et al. 2015).

\section{KNOWLEDGE GAPS IN THE MANAGEMENT OF MLN}

Three components - the virus, its vector, and a susceptible host-must come together in a suitable environment for a virus disease to occur (Redinbaugh and Zambrano-Mendoza 2014). The "sudden" appearance of emerging virus diseases could be associated with introduction of either a nonindigenous pathogen or its vector into a region (Colvin et al. 2006) where host germplasm has little or no resistance to new pathogens (Thresh 2006). We have some clues about the "perfect storm" of conditions that led to the massive outbreak of MLN in eastern Africa: widespread use of highly susceptible hybrids, the presence or increase in populations of a thrips vector for MCMV transmission, the presence of SCMV, and continuous cropping of maize. In addition, there is some indication of apparently high rates of seed contamination by MCMV, and potential alternative hosts of the virus are present. However, we still do not know what tipping point brought the disease to the forefront.

MLN is frequently referred to as having "spread" quickly from Bomet in western Kenya, where it was first identified (Wangai et al. 2012 b). However, the mechanism by which the MCMV could have been identified over such a broad geographic region within 3 years remains unclear. Because thrips can be identified in nearly all fields affected with MLN, there is a growing consensus that within-field spread of MCMVoccurs through vectors. Factors controlling spread of the disease regionally are less clear, although many hypothesize that seed transmission of the virus may be playing a major role. Careful experiments to characterize seed transmission of MCMV in East African maize germplasm are required to confirm this hypothesis. Understanding the rate of MCMV transmission in seed is critical for evaluating the potential for accidental movement of MCMV into virus-free areas, and for development of protocols for producing seed with no or reduced levels of MCMV transmission through seed.

Several studies have pointed out that the sequences of the MCMV isolates from eastern Africa are similar to those from Asia (Adams et al. 2013, 2014). Although the data support a shared origin for the
Asian and African isolates, the MCMVepidemics in China and East Africa emerged almost simultaneously in the two regions. Thus, questions remain about the origin of MCMV in East Africa. Certainly, a deeper investigation of the epidemiology of this relatively new epidemic could provide information that will help prevent future occurrences in maize and other crops.

Development of robust, research-based approaches for disease control and communication of these approaches to farmers is critical. Studies to develop a "risk index" based on epidemiology, varietal response, and hot spots could be useful as a decision support system for farmers in the region. If transmission through seed is demonstrated to be a significant issue, identification of methods for the production, identification, and distribution of "clean" seed (i.e., seed producing uninfected plants) will be important. A campaign to educate farmers on the risks associated with recycling seed or buying untested seed will also be important. In addition the efficacy of crop rotation, planting practices and field maintenance for disease control need to be evaluated. If crop rotation is effective, then new crops and means for marketing these crops are also needed.

In the long run, controlling MLN through the use of resistant hybrids and cultivars, in combination with improved agronomic practices, is likely the best solution. Because closely linked markers and excellent sources for resistance to SCMV are available (Jones et al. 2007; Redinbaugh and Zambrano-Mendoza 2014), markerassisted breeding to improve SCMV resistance in the maize germplasm grown in the region must begin immediately, because this disease alone causes significant losses. Some promising lines have been identified with improved response to MCMV. These putative resistance sources require further characterization to determine whether they are resistant to or tolerant of MCMV infection, and to identify genes and QTL associated with resistance for marker-assisted breeding. To date, no maize lines with true immunity or strong resistance (i.e., the virus is absent from or is present at very low levels in plant tissue) to MCMV have been identified (J. Brewbaker, personal communication), and further investigation of maize germplasm for strong resistance is warranted. The potential for transgenic resistance the viruses should also be determined (Murry et al. 1993). It is possible that resistance to MLN vectors could further strengthen pathogen resistance. Deploying immune or resistant lines is optimal, because it has the potential to prevent maize from being a reservoir of MCMV and, thus, prevent virus movement into less-tolerant genotypes.

\section{ACKNOWLEDGMENTS}

We thank K. Willie (USDA-ARS), J. Vacha (USDA-ARS), and G. Raikhy (Washington State University) for providing expert technical assistance; One Acre Fund for allowing us to share results of MCMV and SCMV surveys done in collaboration with ARS; the Bill and Melinda Gates Foundation (BMGF) for support to M. G. Redinbaugh, C. L. Niblett, and B. E. Lockhart (contracts 24531 and 23512); BMGF and Syngenta Foundation for Sustainable Agriculture for providing financial support and CGIAR Research Program on Maize for implementing a project on MLN in eastern Africa; CRP MAIZE, CIMMYT, the Kenya Agricultural Productivity and Agribusiness Project (KAPAP) Collaborative Research Projects, USAID's AfricaRISING project in Tanzania, the Ministry of AgricultureKenya, and KALRO for their support; and One Acre Fund, USDA Foreign Agriculture Service, and USDA-ARS Office of International Research Programs for travel assistance for M. G. Redinbaugh and C. L. Niblett.

\section{LITERATURE CITED}

Adams, I. P., Harju, V. A., Hodges, T., Hany, U., Skelton, A., Rai, S., Deka, M. K., Smith, J., Fox, A., Uzayisenga, B., Ngaboyisonga, C., Uwumukiza, B., Rutikanga, A., Rutherford, M., Ricthis, B., Phiri, N., and Boonham, N. 2014. First report of maize lethal necrosis disease in Rwanda. New Dis. Rep. 29:22. Adams, I. P., Miano, D. W., Kinyua, Z. M., Wangai, A., Kimani, E., Phiri, N., Reeder, R., Harju, V., Glover, R., Hany, U., Souza-Richards, R., Deb Nath, P., Nixon, T., Fox, A., Barnes, A., Smith, J., Skelton, A., Thwaites, R., Mumford, R., and Boonham, N. 2013. Use of next-generation sequencing for the identification and characterization of Maize chlorotic mottle virus 
and Sugarcane mosaic virus causing maize lethal necrosis in Kenya. Plant Pathol. 62:741-749.

Bockelman, D. L., Claflin, L. E., and Uyemoto, J. K. 1982. Host range and seed transmission studies of Maize chlorotic mottle virus in grasses and corn. Plant Dis. 66:216-218.

Brault, V., Uzest, M., Monsion, B., Jacquot, E., and Blanc, S. 2010. Aphids as transport devices for plant viruses. C. R. Biol. 333:524-538.

Cabanas, D., Watanabe, S., Higashi, C. H. V., and Bressan, A. 2013. Dissecting the mode of Maize chlorotic virus (Tombusviridae: Machlomovirus) transmission by Frankliniella williamsi (Thysanoptera: Thripidae). J. Econ. Entomol. 106:16-24.

Carrera-Martinez, H., Lozoya-Saldana, H., Mendoza-Zamora, C., and Alvizo-Villasana, H. 1989. Immunoabsorcion enzimatica (ELISA) en Ia identificacion y distribucion del virus moteado clorotico del maiz (VMCM) en el estado de Mexico. Rev. Mex. Fitopatol. 7:20-25.

Castillo, J., and Hebert, T. T. 1974. Nueva enfermedad virosa afectando al maíz en el Peru. Fitopatologia 9:79-84.

Castillo-Loayza, J. 1976. Maize virus and virus-like diseases in Peru. Pages 40-44 in: Int. Maize Virus Dis. Colloq. Workshop. L. E. Williams, D. T. Gordon, and L. R. Nault, eds. OARDC, Wooster, OH.

Clark, M. F., and Adams, A. N. 1977. Characteristics of microplate method of enzyme-linked immunosorbent assay for detection of plant viruses. J. Gen. Virol. 34:475-483.

Colvin, J., Omong, C. A., Govindappa, M. R., Stevenson, P. C., Maruthi, M. N., Gibson, G., Seal, S. E., and Muniyappa, V. 2006. Host-plant viral infection effects on arthropod vector population growth, development and behaviour: Management and epidemiological implications. Adv. Virus Res. 67:419-452.

Deng, T. C., Chou, C. M., Chen, C. T., Tsai, C. H., and Lin, F. C. 2014. First report of Maize chlorotic mottle virus on sweet corn in Taiwan. Plant Dis. 98:1748

Doupnik, B. 1979. Status of corn lethal necrosis: 1979 update. Pages 16-24 in: Proc. 34th Annu. Corn Sorghum Res. Conf. Chicago. American Seed Trade Association, Corn and Sorghum Division.

FAOSTAT. 2010. Statistical databases and data-sets of the Food and Agriculture Organization of the United Nations. Online publication. http://www. fao.org/docrep/015/am081m/am081m00.htm

Goldberg, K. B., and Brakke, M. K. 1987. Concentration of Maize chlorotic mottle virus increased in mixed infections with Maize dwarf mosaic virus, strain-B. Phytopathology 77:162-167.

Handley, J. A., Smith, G. R., Dale, J. L., and Harding, R. M. 1998. Sequence diversity in the coat protein coding region of twelve sugarcane mosaic potyvirus isolates from Australia, USA and South Africa. Arch. Virol. 143: 1145-1153.

Jarugula, S., Alabi, O. J., Martin, R. R., and Naidu, R. A. 2010. Genetic variability of natural populations of Grapevine leafroll-associated virus 2 in Pacific Northwest vineyards. Phytopathology 100:698-707.

Jensen, S. G., Wysong, D. S., Ball, E. M., and Higley, P. M. 1991. Seed transmission of maize chlorotic mottle virus. Plant Dis. 75:497-498.

Jiang, X. Q., Meinke, L. J., Wright, R. J., Wilkinson, D. R., and Campbell, J. E. 1992. Maize chlorotic mottle virus in Hawaiian-grown maize - vector relations, host range and associated viruses. Crop Prot. 11:248-254.

Jones, M. W., Boyd, E. C., and Redinbaugh, M. G. 2011. Responses of maize (Zea mays L.) near isogenic lines carrying Wsm1, Wsm2, and Wsm3 to three viruses in the Potyviridae. Theor. Appl. Genet. 123:729-740.

Jones, M. W., Redinbaugh, M. G., and Louie, R. 2007. The Mdm1 locus and maize resistance to Maize dwarf mosaic virus. Plant Dis. 91:185-190.

Klingkong, T., and Sutabutra, T. 1982. A new virus disease of maize in Thailand. Pages 191-193 in: Proc. Int. Maize Virus Dis. Colloq. Workshop. D. T. Gordon, J. K. Knoke, L. R. Nault, and R. M. Ritter, eds. OARDC, Wooster, $\mathrm{OH}$.

Kusia, E. S., Subramanian, S., Nyasani, J. O., Khamis, F., Villinger, J., Ateka, E., and Pappu, H. R. First report of lethal necrosis disease associated with co-infection of finger millet with Maize chlorotic mottle virus and Sugarcane mosaic virus in Kenya. Plant Dis. In press.

Li, L., Wang, X. F., and Zhou, G. H. 2011. Effects of seed quality on the proportion of seed transmission for Sugarcane mosaic virus in maize. Cereal Res. Commun. 39:257-266.

Li, Y. Q., Liu, R. Y., Zhou, T., and Fan, Z. F. 2013. Genetic diversity and population structure of Sugarcane mosaic virus. Virus Res. 171: 242-246.

Lommel, S. A., McCain, A. H., and Morris, T. J. 1982. Evaluation of indirect enzyme-linked immunosorbent assay for the detection of plant viruses. Phytopathology 72:1018-1022.

Louie, R. 1980. Sugarcane mosaic virus in Kenya. Plant Dis. 64:944-947.

Lukanda, M., Owati, A., Ogunsanya, P., Valimunzigha, K., Katsongo, K., Ndemere, H., and Kumar, L. P. 2014. First report of Maize chlorotic mottle virus infecting maize in the Democratic Republic of the Congo. Plant Dis. 98:1448-1449.
Meyer, M. D., and Pataky, J. K. 2010. Increased severity of foliar diseases of sweet corn infected with maize dwarf mosaic and sugarcane mosaic viruses. Plant Dis. 94:1093-1099.

Maule, A. J., and Wang, D. 1996. Seed transmission of plant viruses: A lesson in biological complexity. Trends Microbiol. 4:153-158.

Morales, F. J., Arroyave, J. A., Castillo, J., and De Leon, C. 1999. Cytopathology of maize chlorotic mottle virus in Zea mays L. Maydica 44:231-235.

Moritz, G., Brandt, S., Triapitsyn, S., and Subramanian, S. 2013. Identification and information tools for pest thrips in East Africa. QAAFI Biological Information Technology (QBIT), The University of Queensland, Brisbane, Australia.

Murry, L. E., Elliott, L. G., Capitant, S. A., West, J. A., Hanson, K. K., Scarafia, L., Johnston, S., Delucaflaherty, C., Nichols, S., Cunanan, D., Dietrich, P. S., Mettler, I. J., Dewald, S., Warnick, D. A., Rhodes, C., Sinibaldi, R. M., and Brunke, K. J. 1993. Transgenic corn plants expressing MDMV strain-B coat protein are resistant to mixed infections of maize-dwarf mosaic-virus and maize chlorotic mottle virus. Nat. Biotechnol. 11:1559-1564.

Nault, L. R., Negi, L. S., Niblett, C. L., Gordon, D. T., Styer, W. E., and Coffey, M. E. 1978. Transmission of maize chlorotic mottle virus by chrysomelid beetles. Phytopathology 68:1071-1074.

Nelson, S., Brewbaker, J., and Hu, J. 2011. Maize chlorotic mottle. PD-79. College of Tropical Agriculture and Human Resources, University of Hawaii at Manoa. Online publication. http://www.ctahr.hawaii.edu/oc/ freepubs/pdf/PD-79.pdf

Niblett, C. L., and Claflin, L. E. 1978. Corn lethal necrosis a new virus disease of corn in Kansas. Plant Dis. Rep. 62:15-19.

Nyasani, J. O., Meyhöfer, R., Subramanian, S., and Poehling, H.-M. 2012. Effect of intercrops on thrips species composition and population abundance on French beans in Kenya. Entomol. Exp. Appl. 142:236-246.

Phillips, N. J., Uyemoto, J. K., and Wilson, D. L. 1982. Maize chlorotic mottle virus and crop rotation: Effect of sorghum on virus incidence. Plant Dis. 66: 376-379.

Redinbaugh, M. G., and Zambrano-Mendoza, J. L. 2014. Control of virus diseases in maize. Adv. Virus Res. 90:391-429.

Riley, D. G., Joseph, S. V., Srinivasan, R., and Diffie, S. 2011. Thrips vectors of tospoviruses. J. Integr. Pest Manage. 2:1-I10.

Scheets, K. 1998. Maize chlorotic mottle machlomovirus and Wheat streak mosaic rymovirus concentrations increase in the synergistic disease corn lethal necrosis. Virology 242:28-38.

Scheets, K. 2004. Maize chlorotic mottle. Pages 642-644 in: Viruses and Virus Diseases of Poaceae (Gramineae). H. Lapierre and P. A. Signoret, eds. Institut National de la Rocherche Agronomique, Paris.

Semagn, K., Babu, R., Hearne, S., and Olsen, M. 2014. Single nucleotide polymorphism genotyping using Kompetitive Allele Specific PCR (KASP): Overview of the technology and its application in crop improvement. Mol. Breed. 33:1-14.

Semagn, K., Beyene, Y., Babu, R., Nair, S., Gowda, M., Das, B., Tarekenge, A., Mugo, S., Mahuku, G., Worku, M., Warburton, M. L., Olsen, M., and Prasanna, B. M. 2015. Quantitative trait loci mapping and molecular breeding for developing stress resilient maize for sub-Saharan Africa. Crop Sci. 55:1-11.

Shiferaw, B., Prasanna, B. M., Hellin, J., and Banziger, M. 2011. Crops that feed the world. 6. Past successes and future challenges to the role played by maize in global food security. Food Sec. 3:307-327.

Stewart, L. R., Teplier, R., Todd, J. C., Jones, M. W., Cassone, B. C., Wijeratne, S., Wijeratne, A., and Redinbaugh, M. G. 2014. Viruses in maize and Johnsongrass in southern Ohio. Phytopathol. 104:1360-1369.

Teyssandier, E. E., Dal Bo, E., and Nome, S. F. 1981. Maize virus diseases in Argentina. Pages 93-99 in: Proc. Int. Maize Virus Dis. Colloq. Workshop. Ohio Agricultural Research and Development Center, Wooster, OH.

Thresh, J. M. 2006. Plant virus epidemiology: The concept of host genetic vulnerability. Adv. Virus Res. 67:89-125.

Uyemoto, J. K. 1983. Biology and control of maize chlorotic mottle virus. Plant Dis. 67:7-10.

Uyemoto, J. K., Bockelman, D. L., and Claflin, L. E. 1980. Severe outbreak of corn lethal necrosis disease in Kansas. Plant Dis. 64:99-100.

Uyemoto, J. K., Claflin, L. E., and Wilson, D. L. 1981. Maize chlorotic mottle and maize dwarf mosaic viruses: Effect of single and double inoculations on symptomatology and yield. Plant Dis. 65:39-41.

Wang, Q., Zhou, X. P., and Wu, J. X. 2014. First report of Maize chlorotic mottle virus infecting sugarcane (Saccharum officinarum). Plant Dis. 98:572.

Wangai, A., Sikinyi, E., Ochieng, J., Miyogo, S., Karanja, T., Odour, H., Kimani, E., Irungu, J., Kinyua, Z., Ngaruiya, P., Ligeyo, D., and Kipkemboi, S. 2012a. Joint assessment report: Report on status of maize lethal necrosis disease and general maize performance. Ministry of Agriculture, Kenya. Online publication. http://www.fao.org/fileadmin/user_upload/ drought/docs/Maize\%20Lethal\%20Necrotic\%20Disease\%20in\%20Kenya Joint\%20Assessment\%20Report\%20(July\%202012).pdf 
Wangai, A. W., Redinbaugh, M. G., Kinyua, Z. M., Mahuku, G., Sheets, K., and Jeffers, D. 2012b. First report of Maize chlorotic mottle virus and maize lethal necrosis in Kenya. Plant Dis. 96:1582.

Xie, L., Zhang, J. Z., Wang, Q. A., Meng, C. M., Hong, J. A., and Zhou, X. P. 2011. Characterization of Maize chlorotic mottle virus associated with maize lethal necrosis disease in China. J. Phytopathol. 159:191-193.
Zambrano, J. L., Jones, M. W., Brenner, E., Francis, D. M., Tomas, A., and Redinbaugh, M. G. 2014. Genetic analysis of resistance to six virus diseases in a multiple virus-resistant maize inbred line. Theor. Appl. Genet. 127:867-80.

Zhao, M., Ho, H., Wu, Y., He, Y., and Li, M. 2014. Western flower thrips (Frankliniella occidentalis) transmits Maize chlorotic mottle virus. J. Phytopathol. 162:532-536. 